\title{
A SIMPLE LIQUID CHROMATOGRAPHIC METHOD FOR SIMULTANEOUS ESTIMATION OF AZITHROMYCIN, FLUCONAZOLE AND ORNIDAZOLE IN BULK AND PHARMACEUTICAL DOSAGE FORMS
}

\author{
NARENDER MALOTHU ${ }^{\mathrm{a}}$, SRI BHARGAVI KONA ${ }^{\mathrm{b}}$, BALAKRISHNA MUTHYALA ${ }^{\mathrm{b}}$, PADMALATHA KATAMANENI \\ a*Department of Pharmaceutical Analysis, KL College of Pharmacy, KLEF Deemed to be University, Vaddeswaram, Guntur, bDepartment of \\ Pharmaceutical Analysis, Vijaya Institute of Pharmaceutical Sciences for Women (VIPW), Enikepadu, Vijayawada, Krishna, Andhra Pradesh \\ Email: narendermalothu@gmail.com
}

Received: 27 Aug 2018 Revised and Accepted: 21 Jun 2019

\begin{abstract}
Objective: The objective of the study was to develop and validate a new rapid and more sensitive Reverse Phase High-Performance Liquid Chromatography (RP-HPLC) method for the simultaneous estimation of azithromycin, fluconazole and ornidazole in bulk and pharmaceutical dosage forms.

Methods: Separation was achieved with a cap cell pack C18 column ( 4.6 x $250 \mathrm{~mm}, 5 \mu)$ with an isocratic mobile phase containing a mixture of acetonitrile and phosphate buffer $\mathrm{pH} 4.8$ [adjusted with ortho-phosphoric acid] (50:50 \% v/v) at the flow rate of $1 \mathrm{ml} / \mathrm{min}$ and detection was monitored at $210 \mathrm{~nm}$.

Results: The retention time (Rt) of azithromycin, fluconazole and ornidazole were found to be $4.82 \pm 0.01,5.25 \pm 0.01$ and $6.33 \pm 0.01$ min respectively. The precision was found with $<1.5 \%$ of $\%$ RSD. The calibration curve was linear over the concentration ranging from $500-1000 \mu \mathrm{g} / \mathrm{ml}$ for azithromycin, $75-150 \mu \mathrm{g} / \mathrm{ml}$ for fluconazole and $375-750 \mu \mathrm{g} / \mathrm{ml}$ for ornidazole with the correlation coefficient ( $\mathrm{r}^{2}$ ) of 0.999 . The percentage recovery was found to be within the specified range i.e., $98-102 \%$ for three drugs. Limit of detection (LOD) was found to be $5.810,1.790$ and 4.924 $\mu \mathrm{g} / \mathrm{ml}$, whereas Limit of quantification limits (LOQ) was found to be $9.834,2.667$ and $7.980 \mu \mathrm{g} / \mathrm{ml}$, respectively.
\end{abstract}

Conclusion: A simple isocratic liquid chromatographic method was developed and validated for simultaneous estimation of azithromycin, fluconazole and ornidazole in their formulations. Due to its simplicity, rapidness and specificity, it can be applied for routine quality control analysis of these drugs.

Keywords: Azithromycin, Fluconazole, Ornidazole, Method development, RP-HPLC

(c) 2019 The Authors. Published by Innovare Academic Sciences Pvt Ltd. This is an open-access article under the CC BY license (http://creativecommons.org/licenses/by/4.0/) DOI: http://dx.doi.org/10.22159/ijpps.2019v11i8.29348

\section{INTRODUCTION}

Azithromycin is an antibiotic useful for the treatment of a number of bacterial infections, including middle ear infections, strep throat, pneumonia, traveler's diarrhea and certain other infections. It is also used for sexually transmitted infections such as chlamydia and gonorrhea. It is chemically derived from erythromycin; it acts on bacterial protein synthesis by binding to the $50 \mathrm{~S}$ ribosomal subunit of the bacterial $70 \mathrm{~S}$ ribosome. Thereby, inhibits peptidyl transferase activity and interferes with amino acid translocation during the process of translation.

Fluconazole is an anti-fungal medication which is being used in the number of fungal infections. It is primarily used in the treatment of candidiasis, blastomycosis, coccidiomycosis, cryptococcosis, histoplasmosis, dermatophytosis and pityriasis versicolor. It is a drug of choice in prevention of candidiasis during organ transplantation.

Ornidazole is a drug that cures some protozoan infections. It has been investigated for use in Crohn's disease after bowel resection. It is used for the treatment of stomach, intestinal, urinary tract and genital infections. Formation of redox intermediate (an intracellular metabolite) is believed to be the key component responsible for killing microorganisms.

Combination of azithromycin, fluconazole and ornidazole were coadministered to treat a variety of skin infections such as eczema, fungal skin infections including ringworm etc. Combination therapy commonly administered in the trade name of AF-kit (azithromycin$1000 \mathrm{mg}$; ornidazole-750 mg and fluconazole-150 mg) (fig. 1). As these drugs are frequently co-administered in various infections, an effective, simple and specific analytical method is required for simultaneous estimation, thereby it will be helpful in the quantification of drugs in the formulation as well as in the biological matrices. An extensive literature survey suggests that development of various analytical techniques such as ultraviolet (UV)-visible spectroscopy [1-6], HPLC [6-24], HPTLC [25-28] and LCMS [29-32] for quantification of these drugs either in individual or combination with other drugs. Recently, Krishna et al., [21] reported an RP-HPLC method with the help of sodium dihydrogen ortho-phosphate $(\mathrm{pH}$ 5.2): acetonitrile in the ratio of $70: 30(\% \mathrm{v} / \mathrm{v})$ as mobile phase. Another study by Arunya et al., [24] reported a stability-indicating RP-HPLC method for simultaneous estimation of these drugs with the help of procaine hydrochloride as an internal standard (IS). In the present study, we attempted to achieve a more precise and simple HPLC method by varying the chromatographic conditions. In our study, the separation and quantification were achieved with the help of phosphate buffer ( $\mathrm{pH}-4.8)$ : acetonitrile in 50:50 \% v/v ratio as a mobile phase without using any IS. Moreover, the rapid elution with shorter runtime was observed at $4.82 \pm 0.01,5.25 \pm 0.01$ and $6.33 \pm 0.01 \mathrm{~min}$ for azithromycin, fluconazole and ornidazole, respectively. In addition, the proposed method was validated as per ICH guidelines in terms of various parameters, and the results were found to be within acceptance criteria. In these studies, the method was found to be simple, rapid and more precise.
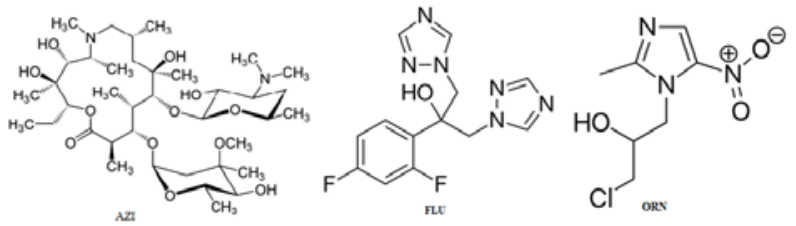

Fig. 1: Chemical structures of azithromycin, fluconazole and ornidazole 


\section{MATERIALS AND METHODS}

\section{Instrumentation}

Lab India UV-3000+double beam UV-Visible spectrophotometer was used to carry out absorption studies and the data were recorded by UV-Win software. Standard cuvettes of $10 \mathrm{~mm}$ path length were used for analysis. Cyber lab LC-100 HPLC system is accomplished with UV-detector, quantitative HPLC was performed on an isocratic mode using cap cell pack C18 (4.6 x $250 \mathrm{~mm}, 5 \mu)$ column with $20 \mu \mathrm{L}$ injections of the sample loop. The output signal was monitored and integrated using Cyber lab LC-100 software. Lifecare ultra-sonic cleaner was used to sonicate the standard and sample solutions.

\section{Chemicals and reagents}

Standard drugs of azithromycin, fluconazole and ornidazole were obtained as gift samples from Cipla Laboratory, Malapur and Aurobindo Pharmaceuticals, Hyderabad. Market formulation (AF-kit, Madras Pharmaceuticals, Chennai) was procured from the local market. HPLC grade acetonitrile and methanol were obtained from Merck Life Sciences, Mumbai, India. Analytical grade solvents and other chemicals were acquired from SD Fine Chemicals, Mumbai, India. Water was obtained from millipore with milli $\mathrm{Q}$ system, filtered through $0.45 \mu$ nylon membrane for the HPLC experiments.

\section{Preparation of phosphate buffer}

Phosphate buffer was prepared by dissolving $13.6 \mathrm{~g}$ of potassium dihydrogen ortho-phosphate in $1000 \mathrm{ml}$ of water (HPLC grade) and $\mathrm{pH}$ was adjusted to 4.8 with ortho-phosphoric acid and solution was filtered through $0.45 \mu$ millipore nylon filter.

\section{Preparation of the mobile phase}

Acetonitrile: phosphate buffer (pH-4.8) in the ratio of 50:50 \% v/v was prepared and it was filtered through $0.45 \mu$ millipore nylon filter. The solution was degassed with ultrasonic cleaner for $15 \mathrm{~min}$. The resultant solution was used as the mobile phase.

\section{Chromatographic conditions}

The method was developed by using a cap cell pack C18 column ( 4.6 x $250 \mathrm{~mm}, 5 \mu$ ) with an isocratic mobile phase which consists a mixture of acetonitrile and potassium dihydrogen ortho-phosphate buffer (pH-4.8 adjusted with ortho-phosphoric acid) in 50:50 \% v/v ratio. The mobile phase was filtered through $0.45 \mu$ millipore nylon filter under vacuum filtration. Flow rate of the mobile phase was adjusted to $1 \mathrm{ml} / \mathrm{min}$. The eluted compounds were detected at the wavelength of $210 \mathrm{~nm}$. The sample injection volume was $20 \mu \mathrm{l}$.

\section{Preparation of a standard mixture of azithromycin, fluconazole} and ornidazole

Transfer $100 \mathrm{mg}$ of azithromycin, $15 \mathrm{mg}$ of fluconazole and $75 \mathrm{mg}$ of ornidazole into a $100 \mathrm{ml}$ of volumetric flask and add $70 \mathrm{ml}$ of diluent. Then it was sonicated for $15 \mathrm{~min}$ and the volume made up to $100 \mathrm{ml}$ with diluent. The resulted solution $(20 \mu \mathrm{l})$ was injected into the HPLC system by employing optimized chromatographic conditions.

\section{Preparation of sample mixture of azithromycin, fluconazole and ornidazole}

Twenty tablets of each of azithromycin, fluconazole and ornidazole (AF-Kit) were weighed and the average weight of each tablet was determined individually. The tablets were crushed into a fine powder, accurately weighed tablet powder equivalent to $100 \mathrm{mg}$ $(0.1121 \mathrm{~g})$ of azithromycin, $15 \mathrm{mg}(0.239 \mathrm{~g})$ of fluconazole and 75 $\mathrm{mg}(0.169 \mathrm{~g})$ of ornidazole and transferred into a clean $100 \mathrm{ml}$ volumetric flask. Add $70 \mathrm{ml}$ of diluents, and then sonicated for 15 min to dissolve, made up to the volume with diluents. The resulted solution was filtered through $0.45 \mu$ membrane filter and then above resulted solution $20 \mu \mathrm{l}$ was injected into the HPLC system.

\section{Selection of detection wavelength}

The standard stock solution of azithromycin, fluconazole and ornidazole in the concentration of $10 \mu \mathrm{g} / \mathrm{ml}$ was prepared and each solution was scanned in UV range (200-400 $\mathrm{nm}$ ) in $10 \mathrm{~mm}$ path length against the solvent blank. The overlain spectrum of three drugs was recorded against solvent blank

\section{Method validation}

Method validation was performed using standard and sample solutions of analytes as per ICH guidelines for proposed method [3335]. The following validation parameters performed such as specificity, linearity, precision, accuracy, robustness, LOD and LOQ etc.

\section{RESULTS}

The purpose of the present study was to develop a rapid and sensitive RP-HPLC method for the simultaneous estimation of azithromycin, fluconazole and ornidazole in their dosage form using cap cell pack C18 analytical column with UV detection.

\section{Selection of detection wavelength}

The study of the absorption spectrum for three drugs revealed that well-defined $\Lambda_{\max }$. The iso-absorptive point was obtained at $210 \mathrm{~nm}$ for three drugs at the given concentration. Obtained wavelength maxima and iso-absorptive point for the three drugs were used for the simultaneous estimation by using RP-HPLC method. The overlain spectrum of azithromycin, fluconazole and ornidazole was shown in fig. 2.

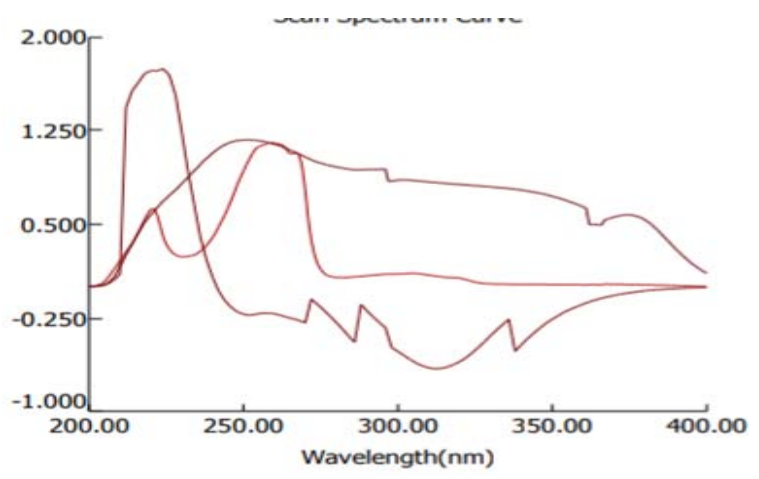

Fig. 2: Overlain spectrum of azithromycin, fluconazole and ornidazole

\section{Method optimization}

Optimization of chromatographic conditions for isocratic RP-HPLC detection, parameters such as mobile phase composition, $\mathrm{pH}$ (4.8-6.3) and flow rate $(1 \mathrm{ml} / \mathrm{min} \pm 0.2)$ were varied for system suitability studies. The variation in the mobile phase led to considerable changes in the chromatographic parameters like asymmetric factor, capacity factor and retention time (Rt). Varying in $\mathrm{pH}$ showed that optimized conditions were reached at $\mathrm{pH} 4.8$, producing well resolved and sharp peaks for three drugs. Henceforth, in the present method, the acetonitrile and phosphate buffer (50:50 \% v/v) $(\mathrm{pH}-4.8)$ was used as a mobile phase with $1.0 \mathrm{ml} / \mathrm{min}$ flow rate as optimal conditions. The detection of peaks achieved at $210 \mathrm{~nm}$ for the three analyte drugs. For quantitative determination of azithromycin, fluconazole and ornidazole in formulations, initially mixed standard solutions in appropriate concentrations were injected into the column and Rt's of azithromycin, fluconazole and ornidazole was found to be $4.82 \pm 0.01$, $5.25 \pm 0.01$ and $6.33 \pm 0.01 \mathrm{~min}$, respectively (fig. 3).

\section{Method validation}

Method validation was performed as per ICH guidelines for simultaneous determination of the azithromycin, fluconazole and ornidazole. The results of parameters such as specificity, linearity, precision, accuracy, robustness, detection limit, quantification limit were described in the following sections.

\section{Specificity}

No interference of additives peak was found in the chromatogram for three drugs in tablet formulation, which indicates the proposed method is specific. Blank determination also performed where no appearance or interference of peaks observed. 


\section{Linearity}

Standard solutions at six different concentration levels ranging from $500-1000 \mu \mathrm{g} / \mathrm{ml}$ for azithromycin, $75-150 \mu \mathrm{g} / \mathrm{ml}$ for fluconazole and $375-750 \mu \mathrm{g} / \mathrm{ml}$ for ornidazole were prepared and analyzed in order to demonstrate the linearity relationships. For linearity study, the standard solutions were prepared as per label claim amount in the tablets. The regression curve was obtained by plotting the peak area $\mathrm{v} / \mathrm{s}$ concentration of each analyte (fig. 4-6). It was obtained by leastsquares method [15]. The correlation coefficient $\left(\mathrm{r}^{2}\right)$ values were found to 0.999 for all the drugs. Detailed Linearity data were summarized in table 1 .

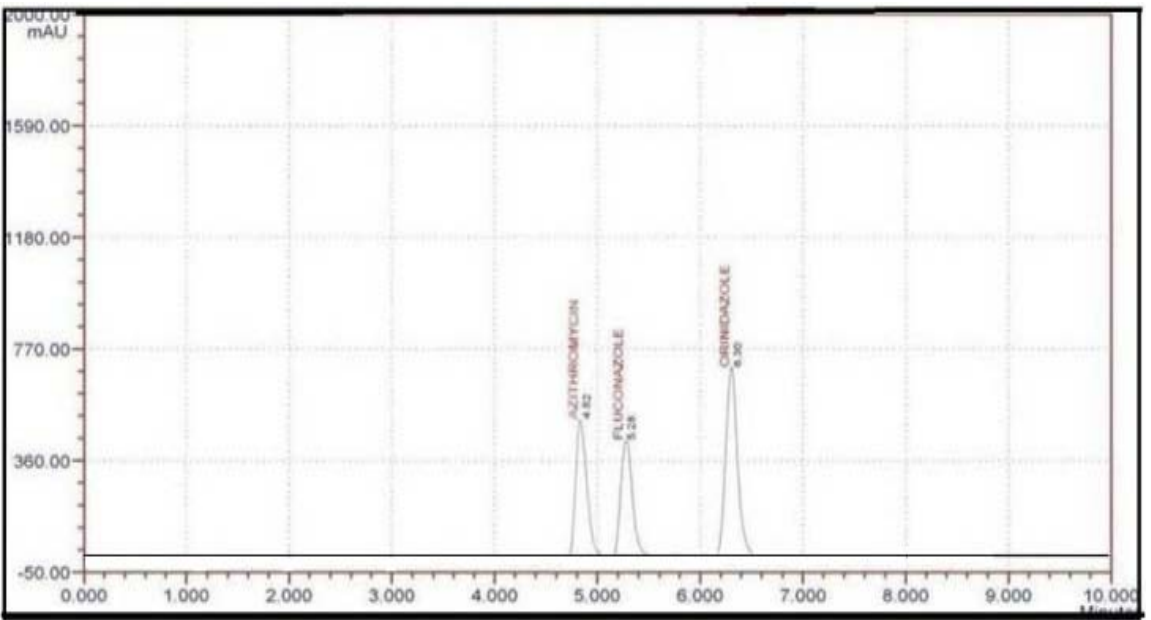

Fig. 3: Standard chromatogram of azithromycin, fluconazole and ornidazole in acetonitrile and phosphate buffer pH-4.8 (50:50\%v/v)

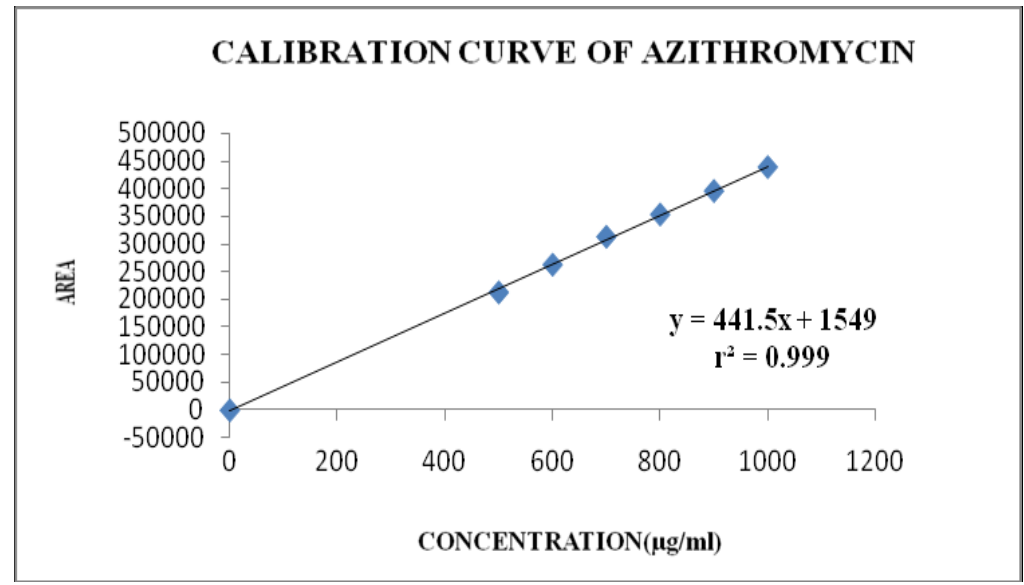

Fig. 4: Calibration curve of azithromycin $(1000-500 \mu \mathrm{g} / \mathrm{ml})$

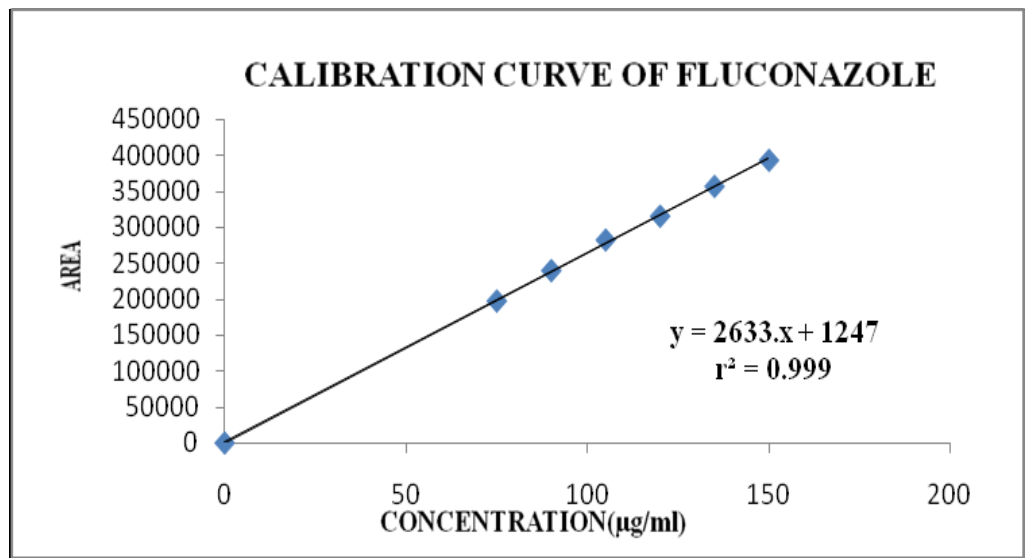

Fig. 5: Calibration curve of fluconazole $(75-150 \mu \mathrm{g} / \mathrm{ml})$ 


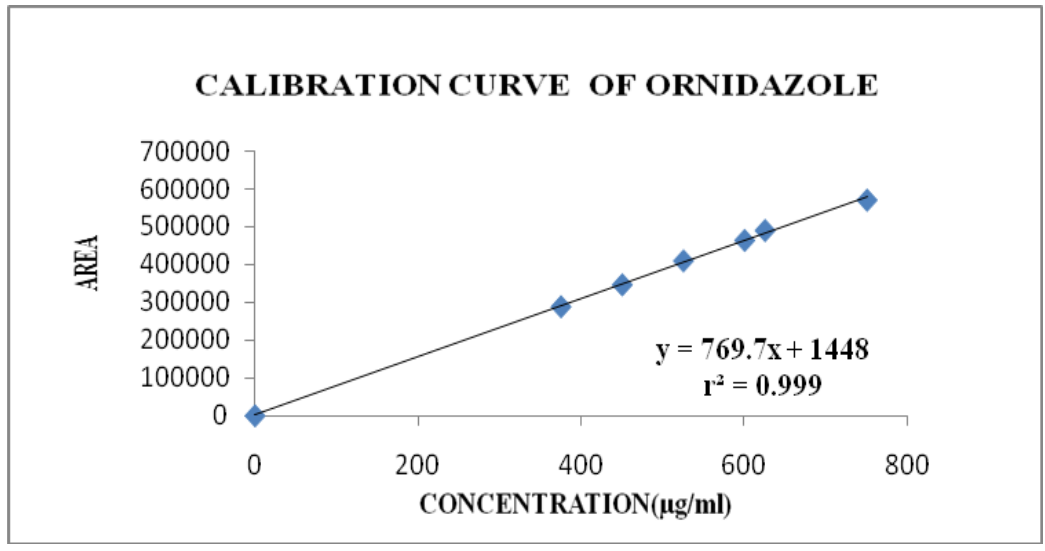

Fig. 6: Calibration curve of ornidazole $(375-750 \mu \mathrm{g} / \mathrm{ml})$

Table 1: Linearity data of azithromycin, fluconazole, ornidazole

\begin{tabular}{|c|c|c|c|}
\hline Analyte & Concentration $(\mu \mathrm{g} / \mathrm{ml})$ & Peak area $(\mathrm{mV})$ & Linear regression equation \\
\hline & 500 & 212776 & \\
\hline \multirow[t]{5}{*}{ Azithromycin } & 600 & 262627 & $y=439.5 x+1549$ \\
\hline & 700 & 312991.6 & $r^{2}=0.999$ \\
\hline & 900 & 395606.7 & \\
\hline & 1000 & 438629 & \\
\hline & 75 & 197526.9 & \\
\hline \multirow[t]{6}{*}{ Fluconazole } & 90 & 239958.4 & $y=2643 x+1247$ \\
\hline & 105 & 282508.2 & $r^{2}=0.999$ \\
\hline & 120 & 315641.9 & \\
\hline & 135 & 357006.2 & \\
\hline & 150 & 438629 & \\
\hline & 375 & 288696 & \\
\hline \multirow[t]{4}{*}{ Ornidazole } & 450 & 346460.7 & $y=772.2 x+1448$ \\
\hline & 525 & 409934.6 & $r^{2}=0.999$ \\
\hline & 600 & 464002.2 & \\
\hline & 625 & 490068.5 & \\
\hline
\end{tabular}

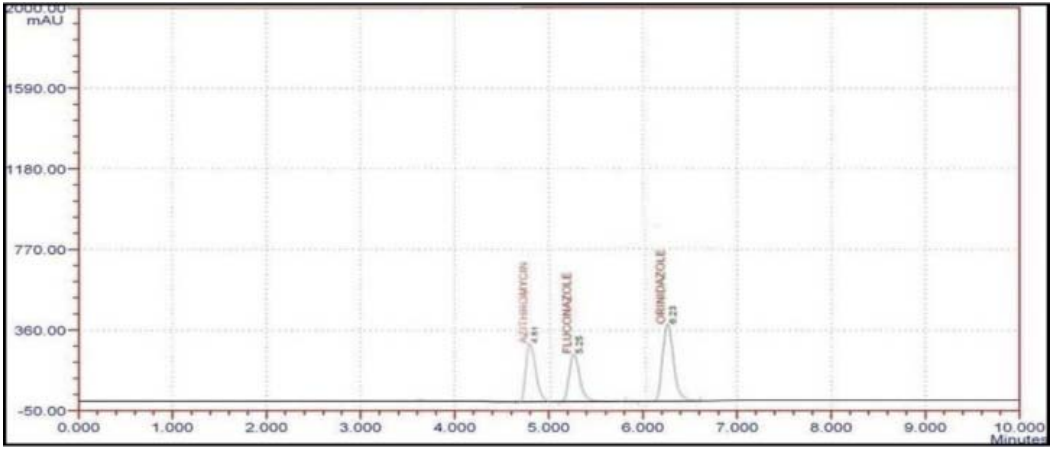

Fig. 7: Chromatogram of $50 \%$ standard addition (level-1)

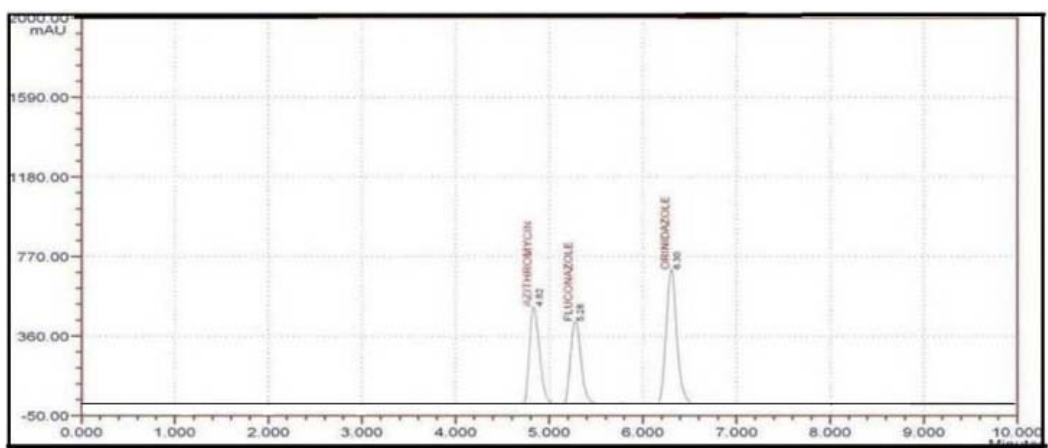

Fig. 8: Chromatogram of $100 \%$ standard addition (level-2) 


\section{Accuracy}

Standard addition experiments were employed for accuracy studies in which the percent (\%) recovery was determined. Accuracy of the method was evaluated in triplicate at three concentration levels, i.e.
$50 \%, 100 \%$ and $150 \%$ of target concentration and the percentages of recoveries were calculated. Resulted chromatograms at these levels were shown in fig. 7-9. Percentage recoveries of three drugs found in between 98.3-101.2\%, which indicates the results obtained were within the potency range (table 2-4).

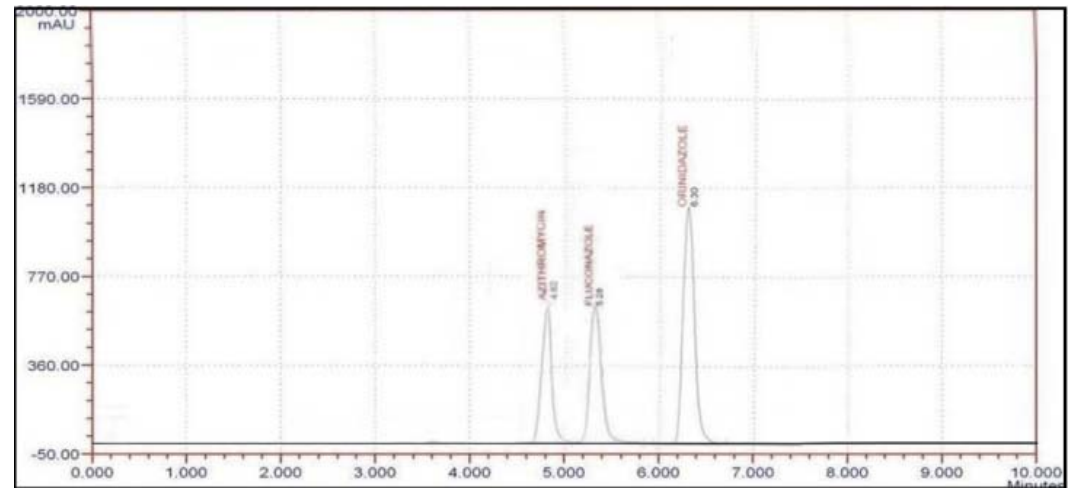

Fig. 9: Chromatogram of $150 \%$ standard addition (level-3)

Table 2: Accuracy data of azithromycin $(n=3)$

\begin{tabular}{|c|c|c|c|c|c|}
\hline S. No. & Spiked level & Sample area & Sample height & \% Recovery & $\%$ mean recovery \pm SD \\
\hline & $50 \%$ & 228316 & 24846 & 101.4 & \\
\hline \multirow[t]{3}{*}{1} & $50 \%$ & 227484 & 24656 & 101.4 & $101.2 \pm 0.288$ \\
\hline & $50 \%$ & 225988 & 24389 & 100.9 & \\
\hline & $100 \%$ & 438654 & 49692 & 99.9 & \\
\hline \multirow[t]{3}{*}{2} & $100 \%$ & 438962 & 49343 & 99.2 & $99.3 \pm 0.472$ \\
\hline & $100 \%$ & 446756 & 49654 & 99.0 & \\
\hline & $150 \%$ & 665493 & 74538 & 98.1 & \\
\hline 3 & $150 \%$ & 668649 & 74832 & 98.2 & $98.3 \pm 0.264$ \\
\hline
\end{tabular}

$\mathrm{n}=$ number of determinations, $\mathrm{SD}=$ Standard deviation, $\%$ RSD $=\%$ Relative standard deviation

Table 3: Accuracy data of fluconazole $(n=3)$

\begin{tabular}{|c|c|c|c|c|c|}
\hline S. No. & Spiked level & Sample area & Sample height & \% Recovery & $\%$ mean recovery \pm SD \\
\hline \multirow[t]{3}{*}{1} & $50 \%$ & 205368 & 21689 & 101.0 & $100 \pm 0.0577$ \\
\hline & $50 \%$ & 204654 & 21594 & 100.0 & \\
\hline & $50 \%$ & 201844 & 21863 & 100.0 & \\
\hline \multirow[t]{3}{*}{2} & $100 \%$ & 395978 & 43189 & 100.3 & \\
\hline & $100 \%$ & 393878 & 43163 & 98.5 & $99.8 \pm 1.209$ \\
\hline & $100 \%$ & 398398 & 43258 & 100.8 & \\
\hline \multirow[t]{2}{*}{3} & $150 \%$ & 603246 & 64783 & 99.1 & $99 \pm 0.0577$ \\
\hline & $150 \%$ & 605685 & 64685 & 99.1 & \\
\hline
\end{tabular}

$\mathrm{n}=$ number of determinations, $\mathrm{SD}=$ Standard deviation, $\% \mathrm{RSD}=\%$ Relative standard deviation

Table 4: Accuracy data of ornidazole $(n=3)$

\begin{tabular}{llllll}
\hline S. No. & Spiked level & Sample area & Sample height & \% Recovery & \%mean recovery \pm SD \\
\hline 1 & $50 \%$ & 295162 & 35021 & 100.8 & 99.8 \\
\\
& $50 \%$ & 293853 & 35683 & 99.8 & $100.1 \pm 0.578$ \\
2 & $50 \%$ & 293345 & 35942 & 100.9 & $100.5 \pm 0.871$ \\
& $100 \%$ & 576369 & 70042 & 701.1 & $99.5 \pm 0.378$ \\
3 & $100 \%$ & 579209 & 70861 & 99.1 & 99.8 \\
\end{tabular}

$\mathrm{n}=$ number of determinations, $\mathrm{SD}=$ Standard deviation, $\%$ RSD $=\%$ Relative standard deviation

\section{Precision}

Precision of the method was determined by injecting the standard and sample solutions of azithromycin, fluconazole and ornidazole separately for six times and measured \% RSD with the help of peak area for all six injections. System precision was established by injecting six replicate injections of standard solutions into the chromatographic system by maintaining the optimized conditions. Method precision was established by injecting six replicate injections of sample solution into the chromatographic system by 
maintaining the optimized conditions. In both cases, the \% RSD found to be $<2 \%$, which indicate the proposed method was more precise. The precision data were summarized in table 5 and 6 .

\section{Robustness}

Robustness experiments were carried by altering chromatographic conditions such as flow rate and detection wavelength to demonstrate any deliberate changes in the proposed method. The changes were made in the chromatographic conditions, viz. change in flow rate by $\pm 0.2 \mathrm{ml} / \mathrm{min}$ and change in the wavelength $\pm 5^{\circ} \mathrm{C}$. The $\%$ RSD was found $<2 \%$ for three drugs even slight change of flow rate as well as detection wavelength (table 7, 8 and 9). As there were no significant variations in elution time for all the three drugs, indicate the method was robust.

Table 5: System precision data of azithromycin, fluconazole and ornidazole $(n=3)$

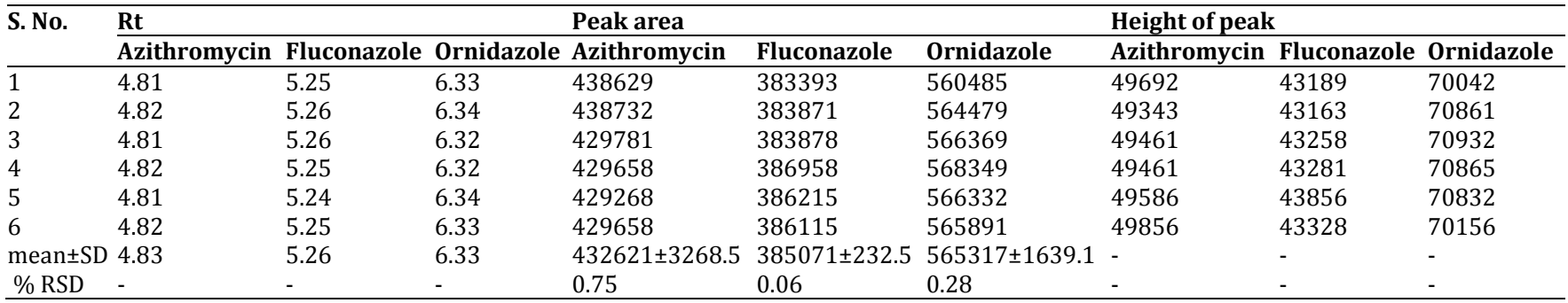

$\mathrm{n}=$ number of determinations, $\mathrm{SD}=$ Standard deviation, $\%$ RSD $=\%$ Relative standard deviation

Table 6: Method precision data of azithromycin, fluconazole and ornidazole $(n=3)$

\begin{tabular}{|c|c|c|c|c|c|c|}
\hline \multirow[t]{2}{*}{ S. No. } & \multicolumn{2}{|c|}{ Azithromycin } & \multicolumn{2}{|c|}{ Fluconazole } & \multicolumn{2}{|c|}{ Ornidazole } \\
\hline & Rt & Peak area & Rt & Peak area & Rt & Peak area \\
\hline Injection-1 & 4.81 & 438654 & 5.25 & 395978 & 6.33 & 576369 \\
\hline Injection-2 & 4.81 & 438962 & 5.26 & 396710 & 6.33 & 579209 \\
\hline Injection-4 & 4.82 & 448756 & 5.25 & 397864 & 6.34 & 578659 \\
\hline Injection-5 & 4.81 & 448851 & 5.25 & 396324 & 6.33 & 578956 \\
\hline Injection-6 & 4.81 & 446231 & 5.26 & 395224 & 6.32 & 576354 \\
\hline mean \pm SD & 4.82 & $444701.0 \pm 3031.6$ & 5.24 & $396474.6 \pm 89.41$ & 6.33 & $577713.1 \pm 932$ \\
\hline$\%$ RSD & - & 0.68 & - & 0.02 & - & 0.16 \\
\hline
\end{tabular}

$\mathrm{n}=$ number of determinations, $\mathrm{SD}=$ Standard deviation, $\%$ RSD $=\%$ Relative standard deviation

Table 7: Robustness data of azithromycin

\begin{tabular}{llll}
\hline Factor & Level & Mean \pm SD of area & \%RSD \\
\hline Flow rate & 0.8 & $427494.5 \pm 1579.11$ & 0.36 \\
(ml/min) & 1 & $438808 \pm 217.78$ & 0.04 \\
& 1.2 & $428998.5 \pm 494.26$ & 0.11 \\
Wavelength & 205 & $554261 \pm 84.852$ & 0.01 \\
$(\mathrm{~nm})$ & 210 & $435941.7 \pm 3800.6$ & 0.87 \\
& 215 & $544333 \pm 13231.3$ & 0.16 \\
\hline
\end{tabular}

$\mathrm{n}=$ number of determinations, $\mathrm{SD}=$ Standard deviation, $\%$ RSD $=\%$ Relative standard deviation

Table 8: Robustness data of fluconazole

\begin{tabular}{llll}
\hline Factor & Level & Mean \pm SD of area & \%RSD \\
\hline Flow rate & 0.8 & $385962.5 \pm 744.58$ & 0.19 \\
(ml/min) & 1 & $396168 \pm 268.70$ & 0.06 \\
Wavelength(nm) & 1.2 & $386261.5 \pm 451.84$ & 0.11 \\
& 205 & $484532.5 \pm 1274.91$ & 0.26 \\
& 210 & $383603 \pm 56.56$ & 0.01 \\
\hline
\end{tabular}

$\mathrm{n}=$ number of determinations, $\mathrm{SD}=$ Standard deviation, $\%$ RSD = \% Relative standard deviation

Table 9: Robustness data of ornidazole

\begin{tabular}{llll}
\hline Factor & Level & Mean \pm SD of area & \%RSD \\
\hline Flow rate & 0.8 & $567256 \pm 2265.5$ & 0.39 \\
$(\mathrm{ml} / \mathrm{min})$ & 1 & $577789 \pm 2007.82$ & 0.34 \\
& 1.2 & $568794.5 \pm 207.18$ & 0.03 \\
Wavelength & 205 & $625212.5 \pm 566.39$ & 0.09 \\
$(\mathrm{~nm})$ & 210 & $563655 \pm 268.7$ & 0.04 \\
& 215 & $625656.5 \pm 371.23$ & 0.05 \\
\hline
\end{tabular}

$\mathrm{n}=$ number of determinations, $\mathrm{SD}=$ Standard deviation, $\% \mathrm{RSD}=\%$ Relative standard deviation 


\section{Limits of detection and quantification (LOD and LOQ)}

The sensitivity of the method was measured by calculating the LOD and LOQ. LOD and LOQ were assessed as per ICH guidelines, i.e., at signals to noise ratio of 3:1 and 10:1 respectively by injecting a series of dilute solutions with known concentrations (fig. 10 and 11). The linear regression equation was plotted for concentration $\mathrm{v} / \mathrm{s}$ area of the peak. The standard deviation of y-intercepts and slope were considered for determination of sensitivity ranges for LOD and LOQ (table 10 and 11).

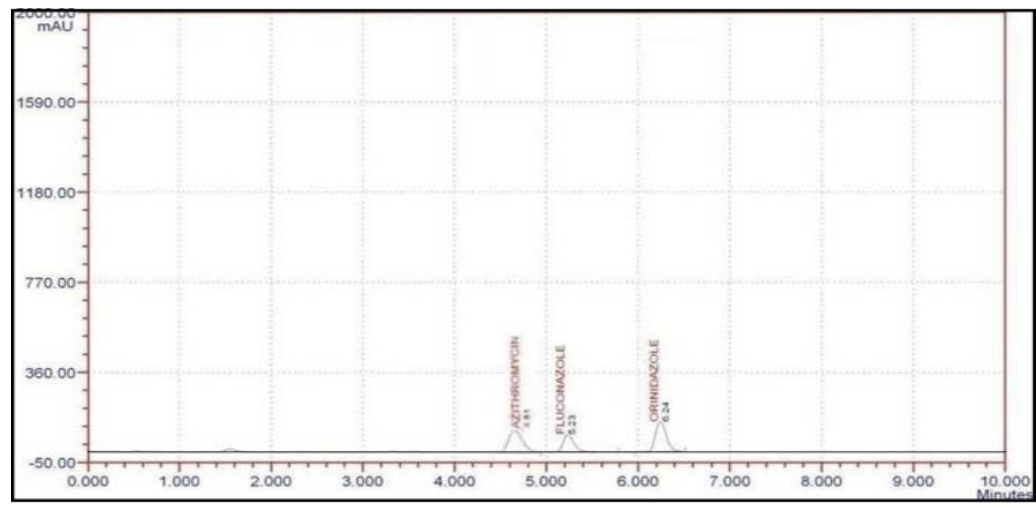

Fig. 10: Chromatogram of LOD studies

Table 10: LOD data of azithromycin, fluconazole and ornidazole $(n=3)$

\begin{tabular}{llll}
\hline S. No. & Drug & Peak area & LOD $(\boldsymbol{\mu g} / \mathbf{m l})$ \\
\hline 1 & Azithromycin & 2157 & 5.810 \\
2 & Fluconazole & 9950 & 1.790 \\
3 & Ornidazole & 57739.2 & 4.924 \\
\hline
\end{tabular}

$\mathrm{n}=$ number of determinations.

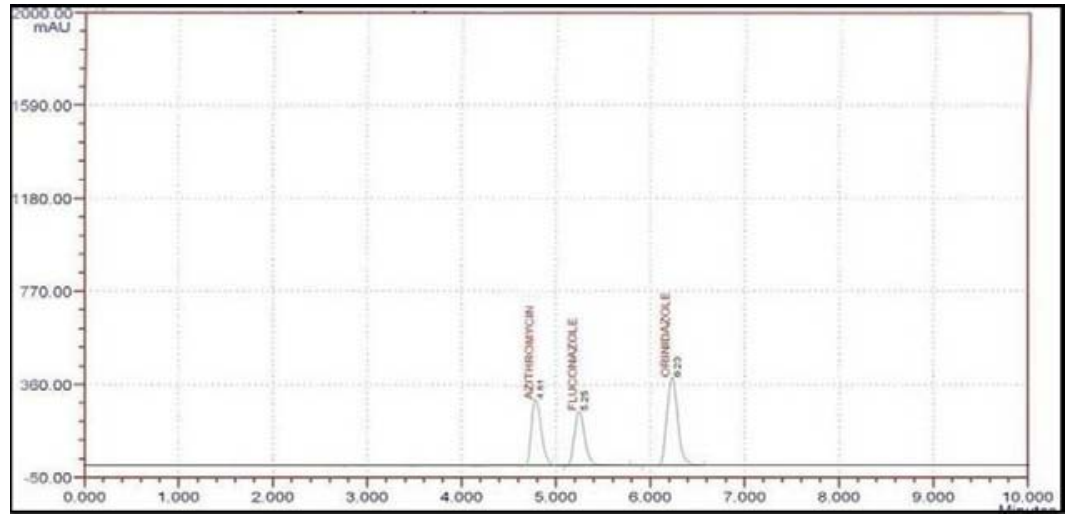

Fig. 11: Chromatogram of LOQ studies

Table 11: LOQ Data of azithromycin, fluconazole and ornidazole $(n=3)$

\begin{tabular}{llll}
\hline S. No. & Drug & Peak area & LOQ $(\boldsymbol{\mu g} / \mathbf{m l})$ \\
\hline 1 & Azithromycin & 3878 & 9.834 \\
2 & Fluconazole & 14887 & 2.667 \\
3 & Ornidazole & 96232.1 & 7.980 \\
\hline
\end{tabular}

$\mathrm{n}=$ number of determinations.

\section{DISCUSSION}

The present study describes the development and validation of a RPHPLC method for simultaneous estimation of azithromycin, fluconazole and ornidazole in bulk drug and in their tablet dosage form. The separation was achieved on cell pack C18 column $(4.6 \times$ $250 \mathrm{~mm}, 5 \mu$ ) with UV detection. The method involves with acetonitrile and phosphate buffer pH-4.8 (50:50 \% v/v) as mobile phase. The flow rate was monitored at $1.0 \mathrm{ml} / \mathrm{min}$ with an injection volume $20 \mu \mathrm{l}$. The separation was achieved by UV-detection wavelength at $210 \mathrm{~nm}$. The peaks were eluted at $4.82 \pm 0.01$ $5.25 \pm 0.01$ and $6.33 \pm 0.01 \mathrm{~min}$ for azithromycin, fluconazole and ornidazole, respectively which was found with a short time of elution and well resolved to that of the reported method [22]

The decrease in buffer content (aqueous content) as well as adjusting $\mathrm{pH}$ at 4.8 of the mobile phase system resulted in rapid elution of fluconazole (RT-5.25 min). The system suitability parameters such as theoretical plates and tailing factor were found to be 8310, 1.0 (azithromycin), 8288, 1.8 (fluconazole) and 11846, 
1.5 (ornidazole). Linearity was found over the concentration range of $500-1000 \mu \mathrm{g} / \mathrm{ml}$ for azithromycin, $75-150 \mu \mathrm{g} / \mathrm{ml}$ for fluconazole and $375-750 \mu \mathrm{g} / \mathrm{ml}$ for ornidazole with a correlation coefficient $\left(\mathrm{r}^{2}\right)$ of 0.999 for three drugs. The method found to be more accurate with $\%$ recoveries of 100-102 \%, 99-100\% and 98-102\% for azithromycin, fluconazole and ornidazole, respectively. LOD values were $5.810 \mu \mathrm{g} / \mathrm{ml}$ (azithromycin), $1.790 \mu \mathrm{g} / \mathrm{ml}$ (fluconazole) and $4.924 \mu \mathrm{g} / \mathrm{ml}$ (ornidazole). LOQ values were $9.834 \mu \mathrm{g} / \mathrm{ml}$ (azithromycin), $2.667 \mu \mathrm{g} / \mathrm{ml}$ (fluconazole) and $7.980 \mu \mathrm{g} / \mathrm{ml}$ (ornidazole). The present liquid chromatographic method was found that it is as more appropriate for simultaneous estimation of such multi-component (three-drug combinations) pharmaceutical dosage forms.

\section{CONCLUSION}

A simple, accurate and precise RP-HPLC method has been developed for the estimation of azithromycin, fluconazole and ornidazole in tablet dosage form using UV-detector. A RP-cell pack C18 column (4.6 × 250 $\mathrm{mm}, 5 \mu$ ) with a mobile phase consisting of acetonitrile and phosphate buffer $(\mathrm{pH}-4.8)(50: 50 \% \mathrm{v} / \mathrm{v})$ at $1 \mathrm{ml} / \mathrm{min}$ flow rate was used and the effluents were monitored at $210 \mathrm{~nm}$. The results obtained by the proposed method were found as highly resolved, rapid with shorter runtime over previous reported methods. The peaks were eluted at $4.82 \pm 0.01,5.25 \pm 0.01$ and $6.33 \pm 0.01 \mathrm{~min}$, respectively. The percentage of recoveries were found as $100-102 \%, 99-100 \%$ and $98-102 \%$ with accepted limits of \% RSD (<2\%) for three drugs, respectively. The present RP-HPLC method developed was well suitable for routine analysis of these drugs in their pharmaceutical formulation and it can be also applicable to biological samples.

\section{ACKNOWLEDGMENT}

Authors are thankful to Cipla Laboratory, Malapur and Aurobindo Pharmaceuticals, Hyderabad for providing API as gift samples. We are also thankful to Principal and Management of Vijaya Institute of Pharmaceutical Sciences for Women, Vijayawada and KL College of Pharmacy, KLEF Deemed to be University, Guntur for allowing us to avail the facilities of experimentations.

\section{AUTHORS CONTRIBUTIONS}

\section{All authors contributed equally to this manuscript}

\section{CONFLICTS OF INTERESTS}

The authors declare no conflict of interest. It has not meant to publish elsewhere. And it has not meant simultaneously presented for publication elsewhere. All authors have decided to the submission to the journal.

\section{REFERENCES}

1. Mubeen G, Prakash V, Somashekar PL, Uvesh K. Spectrophotometric method for determination of ornidazole. Int J ChemTech Res 2009;1:318-21.

2. Singh A, Sharma PK, Majumdar DK. Development and validation of different UV-spectrometric methods for the estimation of fluconazole in bulk and in solid dosage form. Indian J Chem Tech 2011;18:357-62.

3. Rele RV, Sawant SA, Patil SS. Simultaneous spectrophotometric estimation of ofloxacin and ornidazole by first-order derivative spectroscopy method in the combined dosage form. Der Chem Sin 2013;4:43-8.

4. Bhimani S, Sanghvi G, Pethani T, Dave G, Airao V, Sharma T, et al. Development of the UV spectrophotometric method of azithromycin in API and stress degradation studies. Int Lett Chem Phys Astron 2016;68:48-53.

5. Jayanna BK, Nagendrappa G, Arunkumar, Gowda N. Spectrophotometric estimation of azithromycin in tablets. Indian J Pharm Sci 2012;74:365-7.

6. Liew KB, Loh OKG, Tan YTF, Kok-khiang P. Development and application of simple HPLC-UV method for fluconazole quantification in human plasma. Int J Pharm Pharm Sci 2012;4:107-11.

7. Jadhav RS, Kendre PN, Kolhe MH, Lateef SN, Shelke SM, Godge RK. RP-HPLC method for simultaneous estimation of ofloxacin and ornidazole from bulk and tablets. Res J Sci Tech 2009;1:43-6.
8. Meshtam DB, Bagade SB, Tajne MR. Simple HPLC method for simultaneous estimation of fluconazole and tinidazole in combined dose tablet. J Chromatogr Sci 2009;47:885-8.

9. Sadasivudu P, Shastri N, Sadanandam M. Development and validation of RP-HPLC and UV methods of analysis for fluconazole in pharmaceutical solid dosage forms. Int J Chem Tech Res 2009;1:1131-6.

10. Dhandapani B, Thirumoorthy N, Rasheed SH, Kotaiah MR, Anjaneyalu N. Method development and validation for the simultaneous estimation of ofloxacin and ornidazole in tablet dosage form by RP-HPLC. Int J Pharm Sci Res 2010;1:78-83.

11. Raja MS, Shan SH, Perumal P, Moorthy MTS. RP-HPLC method developed and validation for simultaneous estimation and determination of azithromycin and ambroxol hydrochloride in tablets. Int J Chem Tech Res 2010;2:36-9.

12. Yanamandra R, Chaudhary A, Bandaru SR, Patro B, Murthy YLN, Ramaiah PA, et al. UPLC method for simultaneous separation and estimation of secnidazole, fluconazole and azithromycin in pharmaceutical dosage forms. E-J Chem 2010;7:S363-71.

13. Raju CHN, Ramana KV, Rao GD, Thoddi PR. Simultaneous RPHPLC method development and validation of levofloxacin and ornidazole in combined pharmaceutical dosage forms. Int J Chem Sci 2010;8:2145-52.

14. Bodepudi C, Bantu S, Reddy MKO, Shanmugasundaram P, Aanandhi MV. Novel RP-HPLC method development and validation of fluconazole and tinidazole in a combined tablet dosage form. Int J Chem Tech Res 2011;3:1309-17.

15. Venkatesh V, Prabahar AE, Suresh PV, Maheswari CU, Rao NR. RPHPLC method for simultaneous estimation of azithromycin and ambroxol hydrochloride in tablets. Asian J Chem 2011;23:312-4.

16. Khattab FI, Ramadan NK, Hegazy MA, Ghoniem NS. Stabilityindicating methods for the determination of ornidazole in the presence of its degradate according to ICH guidelines. Pharm Anal Acta 2012;3:1000179.

17. Dewan I, Amin T, Hossain MdF, Hasan M, Chowdhury SF, Gazi $\mathrm{M}$, et al. Development and validation of a new HPLC method for the estimation of azithromycin in bulk and tablet dosage form. Int J Pharm Res Sci 2013;4:282-6.

18. Waghule SN, Jain NP, Patani CJ, Patani AC. Method development and validation of HPLC method for determination of azithromycin. Der Pharma Chem 2013;5:166-72.

19. Sathiyasundar R, Veeramanikandan P, Arcot AS, Rajaganapathy K. Analytical method development and method validation of simultaneous determination of tinidazole and fluconazole by RP-HPLC. Int J Chem Pharm Sci 2014;5:105-9.

20. Jain SK, Singh M, Jain R, Jain N. Spectrophotometric and RPHPLC method development and validation for simultaneous estimation of levofloxacin and ornidazole. Int J Pharm Sci Res 2014;5:3370-7.

21. Krishna VR, Krishna KBM, Babu BH. Development and validation of stability-indicating liquid chromatographic method for the simultaneous estimation of azithromycin, fluconazole and ornidazole in the combined dosage form. Indian J Pharm Sci Res 2014;4:176-86.

22. Ghode PD, Pawar SP. Stability indicating HPLC method development and validation for the simultaneous determination of azithromycin and ofloxacin in bulk and its dosage forms. Int J Adv Pharm Anal 2015;5:17-22.

23. Vaidya H, Patel S, Patel D, Pradhan PK, Upadhyay U. Analytical method development and validation of diloxanide furoate and ornidazole in its combined pharmaceutical dosage form. Sch Acad J Pharm 2015;4:398-404.

24. Arunya A, Kavitha KY. Development and validation of stabilityindicating assay method for simultaneous estimation of azithromycin, fluconazole and ornidazole in bulk and its dosage form by RP-HPLC. Am J Pharm Tech Res 2017;7:313-24.

25. Chepurwar SB, Shirkhedkar AA, Bari SB, Fursule RA, Surana SJ. Validated HPTLC method for simultaneous estimation of levofloxacin hemihydrate and ornidazole in the pharmaceutical dosage form. J Chromatograph Sci 2007;45:531-6.

26. Ranjane PN, Gandhi SV, Kadukar SS, Bothara KG. HPTLC determination of cefuroxime axetil and ornidazole in combined tablet dosage form. J Chromatograph Sci 2010;48:26-8. 
27. Rote AR, Kumbhoje PA. Development and validation of HPTLC method for simultaneous estimation of gatifloxacin and ornidazole in human plasma. J Chromatograph Separat Techniq 2011;2:1000115.

28. Gawande VT, Bothara KG, Satija CO. Validated stabilityindicating HPTLC method for cefixime and azithromycin with preparative isolation, identification, and characterization of degradation products. Acta Chromatographica 2017;29:1-7.

29. Xue Min Z, Jie L, Juan G, Quan Sheng Y, Wen Yan W. Determination of azithromycin in human plasma by LC-MS-MS and its pharmacokinetics. Pharmazie 2007;62:255-7.

30. Yuzuak N, Ozden T, Eren S, Toptan S. Analysis of azithromycin in human plasma by LC-MS-MS. Chromatographia 2007; 66:115-8.

31. Wu D, Wade KC, Paul DJ, Barrett JS. A rapid and sensitive LC MS/MS method for determination of fluconazole in human plasma and its application in infants with candida infections. Ther Drug Monit 2009;31:703-9.

32. Kher GJ, Ram VR, Pandiya GG, Joshi HS. Validated LC method for the simultaneous analysis of cefixime and ornidazole in commercial tablets. Int J ChemTech Res 2012;4:1124-36.

33. US FDA Guidance for Industry, ICH Q6A, specifications: test procedure and acceptance criteria for new drug substances and new drug products: chemical substances; 1999.

34. FDA Guidance for Industry-analytical procedures and method validation, chemistry, manufacturing, and controls documentation, Center for Drug Evaluation and Research (CDER) and Center for Biologics Evaluation and Research (CBER); 2000

35. ICH. $\mathrm{Q}_{2}\left(\mathrm{R}_{1}\right)$, Validation of analytical procedures: text and methodology, in proceedings of ICH, Geneva, Switzerland 2005;1:11. 